\title{
Kajian Potensi Bencana Kebumian Wilayah Kecamatan Ngombol, Kabupaten Purworejo, Provinsi Jawa Tengah
}

\author{
Zainun $^{1 *}$, Wahju Krisna Hidajat ${ }^{1}$, Narulita Santi ${ }^{1}$ \\ Departemen Teknik Geologi, Fakultas Teknik, Universitas Diponegoro
}

\begin{abstract}
Abstrak
Kecamatan Ngombol, Kabupaten Purworejo terletak di bagian selatan Provinsi Jawa Tengah yang merupakan salah satu wilayah rawan bencana. Sejak tahun 2008 hingga tahun 2018 terhitung sebanyak 125 kejadian bencana alam di Kabupaten Purworejo. Sebagai langkah awal meminimalkan dampak negatif dari potensi terjadinya bencana alam, dilakukan kajian dan pemetaan zonasi rawan bencana kebumian di daerah Kecamatan Ngombol. Penelitian dilakukan untuk mengetahui faktor-faktor yang berperan terhadap potensi bencana kebumian dan mengetahui zonasi tingkat rawan bencana kebumian di daerah tersebut. Penentuan zona rawan bencana kebumian menggunakan metode overlay dari skor tiap parameter masing-masing bencana. Parameter zona rawan gempabumi meliputi kondisi geologi berupa pasir, kemiringan lereng terdiri dari datar hingga sangat curam, nilai intesitas gempa sebesar II MMI, dan jauh dari zona sesar. Hasil parameter zona rawan banjir berupa tanah aluvial untuk jenis tanah, kemiringan lereng terdiri dari datar hingga sangat curam, nilai curah hujan infiltrasi sebesar 3.245,93 mm.hari/tahun, penggunaan lahan berupa sawah, pemukiman, kebun, ladang, semak belukar dan pasir, nilai kerapatan sungai kurang dari $0,62 \mathrm{~km} / \mathrm{km} 2$ hingga lebih dari $3,1 \mathrm{~km} / \mathrm{km} 2$. Kecamatan Ngombol tergolong sebagai kawasan tipologi A untuk zona rawan gempabumi. Zona rawan banjir terbagi menjadi 3 kelas yaitu $2 \%$ zona tidak rawan, $47 \%$ zona cukup rawan dan $51 \%$ zona sangat rawan.
\end{abstract}

Kata kunci: Banjir; bencana kebumian; gempabumi; Kabupaten Purworejo; Kecamatan Ngombol.

\begin{abstract}
Ngombol Subdistrict, Purworejo District is located in the southern region of Central Java Province which is a disaster-prone area. From 2008 to 2018 there had been 125 natural disasters occured in Purworejo District. As an initial step in minimizing negative impacts of potential natural disasters, a study and mapping of geological hazard-prone zones in Ngombol Subdistrict are conducted. The purpose of the assessment is to apprehend the factors that affects the risk of geological hazards potential and to determine the zoning of geological hazard-prone in the area. Determination of geological hazard-prone zones uses overlay method from scores which is designated to parameters for each hazards. The parameters of earthquake-prone zones are: the geological condition consists of sand; slope ranges from flat to very steep; earthquake intensity value of II MMI; and far from fault zone. The results of flood-prone zones parameters are: the type of soil is alluvial soil; slope ranges from flat to very steep; rainfall infiltration value is 3245.93; land cover consists of rice fields, mk settlements, plantations, fields, shrubs and sand; river density value ranges from less than 0.62 $\mathrm{km} / \mathrm{km} 2$ to more than $3.1 \mathrm{~km} / \mathrm{km} 2$. Ngombol Subdistrict is classified as typology "A" area in earthquake vulnerability scale. Flood-prone zones are divided into 3 classes: $2 \%$ is non-prone zone, $47 \%$ is moderately prone zone and $51 \%$ is very prone zone.
\end{abstract}

Keywords: Flood; geological hazard; earthquake; Purworejo district; Ngombol subdistrict.

\footnotetext{
*Korespondensi: zainunaja5@gmail.com
} 


\section{PENDAHULUAN}

Sejak tahun 2005 hingga tahun 2015, tercatat kurang lebih sebanyak 15.485 becana alam yang terjadi, dengan lebih dari 78\% (11.648) merupakan bencana hidrometeorologi dan hanya sekitar 22\% (3.810) merupakan bencana geologi (Badan Nasional Penanggulangan Bencana, 2016). Badan Nasional Penanggulangan Bencana atau BNPB (2019) menyebutkan sejak tahun 2008 hingga tahun 2018 telah terjadi sebanyak 125 kejadian bencana alam di Kabupaten Purworejo. Dampak yang ditimbulkan dari kejadian bencana alam tersebut berupa kerusakan rumah warga dan korban jiwa. Badan Nasional Penanggulangan Bencana atau BNPB (2019) menyebutkan terdapat 197 rumah rusak berat, 289 rumah rusak sedang, 547 rumah rusak ringan dan 2.102 rumah terendam akibat banjir. Korban jiwa yang terhitung sebanyak 127 orang, 38 orang mengalami luka-luka, dan 18.897 orang mengungsi.

Kecamatan Ngombol, Kabupaten Purworejo terletak di bagian selatan dari Provinsi Jawa Tengah yang tergolong salah satu wilayah rawan bencana. Sebagai langkah awal dalam meminimalkan dampak negatif dari potensi terjadinya bencana alam di waktu yang akan datang serta berlum adanya penelitian terdahulu terkait kebencanaan pada daerah penelitian, maka perlu dilakukan kajian dan pemetaan zonasi rawan bencana kebumian di daerah Kecamatan Ngombol. Penelitian yang dilakukan bertujuan untuk mendapatkan persebaran daerah yang memiliki tingkat dan zona kerawanan bencana gempabumi dan banjir pada wilayah Kecamatan Ngombol.

\section{Geologi Regional}

Bronto (2007) membagi Kabupaten Purworejo menjadi 3 satuan bentang alam, yaitu Dataran Purworejo (DP), Pegunungan Serayu Selatan (PSS), dan Pegunungan Kulom Progo (PKP) (Gambar 1). Berdasarkan Peta Geologi Lembar Kebumen (Asikin dkk, 1992), Kecamatan Ngombol tersusun atas Endapan Pantai pada bagian selatan dan Endapan Aluvium pada bagian utara. Endapan Aluvium tersusun atas lempung, lanau, pasir, kerikil dan kerakal, dan Endapan Pantai berupa pasir terpilah baiksedang. Bronto (2007) menyebutkan Dataran Purworejo tersusun atas Endapan Pantai di bagian selatan, sedangkan Endapan Aluvium Sungai yang tersebar di bagian utara (Gambar 2).

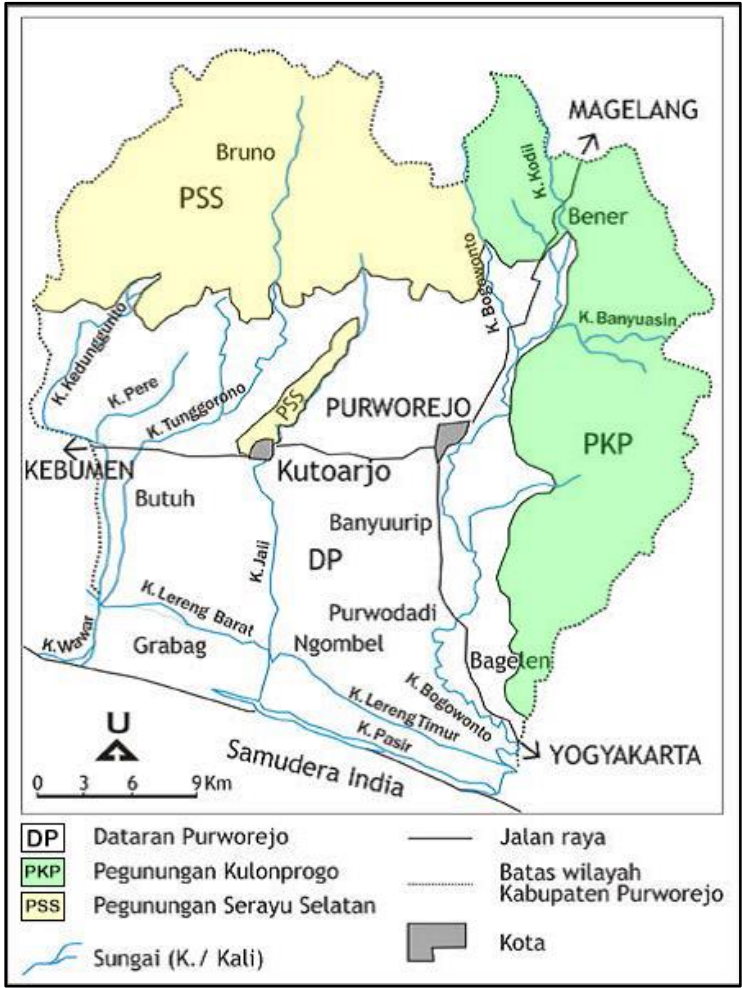

Gambar 1. Peta fisiografi dan pola aliran sungai Kabupaten Purworejo (Modifikasi Bronto, 2007)

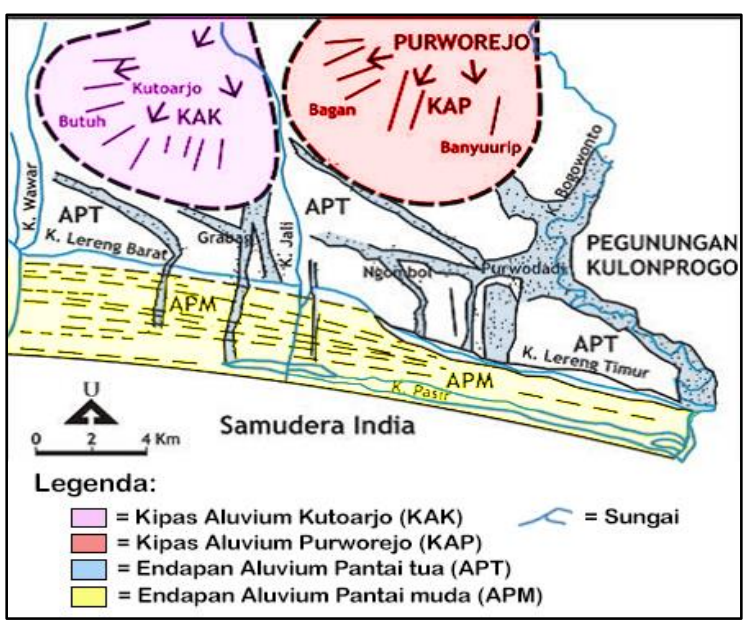

Gambar 2. Peta persebaran endapan aluvium di wilayah Dataran Purworejo (Modifikasi Bronto, 2007).

\section{Penggolongan Morfologi}

Secara umum, analisis morfologi didasarkan pada klasifikasi van Zuidam (1983) yang kemudian disesuaikan dengan temuan lapangan melalui proses pemetaan untuk mengkorelasi jenis bentuklahannya. Penentuan kelerengan tersebut menggunakan parameter persen lereng, derajat kemiringan lereng, dan beda tinggi. seperti yang ditunjukkan pada Tabel 1. 


\section{Pengklasifikasian Tanah}

Pengkasifikasian tanah dalam merumuskan parameter rawan bencana yang melibatkan faktor tanah umumnya menggunakan sistem Unified. Dalam sistem klasifikasi Unified, tanah akan diklasifikasikan ke dalam tanah berbutir kasar (kerikil dan pasir) jika tanah yang lolos saringan 200 kurang dari 50\% (Gambar 3), dan sebagai tanah berbutir halus (lanau/ lempung) jika tanah yang lolos lolos saringan 200 lebih dari $50 \%$ (Gambar 4).

\section{Parameter Zona Rawan Bencana}

\section{1) Zona Rawan Gempa}

Peraturan Menteri Pekerjaan Umum No.21/Prt/M/2007 menentukan zona rawan gempabumi menggunakan beberapa parameter, yaitu geologi (sifat fisik dan keteknikan batuan), kemiringan lereng, kegempaan, dan stuktur geologi. Nilai dan skor dari tiap parameter dapat dilihat pada Tabel 1. Dalam pembobotan akhir yang dilakukan, zonasi kerawanan gempabumi terbagi menjadi 3 jenis berdasarkan aspek total skor yang dihasilkan untuk tingkat kestabilan: stabil (rentang 15-30), kurang stabil (rentang 3145), dan tidak stabil (rentang 46-60). Dari rentang nilai skor sebelumnya, lebih lanjut dapat dikelompokkan menjadi beberapa tipologi kawasan. Untuk mengetahui jenis tipologi kawasan rawan gempabumi dengan acuan rentang skor dapat dilihat pada Tabel 2, dengan rentang skor dari kalkulasi data menggambarkan tipologi wilayah yang tersaji dalam Tabel 3 .

2) Zona Rawan Banjir

Penentuan zona rawan bencana banjir menggunakan beberapa parameter yang digunakan dalam penelitian Nugroho (2013), yaitu kemiringan lereng, jenis tanah, curah hujan, penggunaan lahan, dan kerapatan sungai. Nilai dan skor dari tiap parameter dapat dilihat pada Tabel 4 hingga Tabel 8. Untuk mendapatkan jenis zonasi berdasarkan rentang nilai yang diperoleh, digunakan rumusan tertentu yang disusun oleh Darmawan (2016) yang dapat dilihat pada Persamaan 1.

Tabel 1. Tabel klasifikasi morfologi oleh van Zuidam (1983)

\begin{tabular}{ccccc}
\hline No & Morfologi & Persen Lereng (\%) & Kemiringan Lereng $\left(^{\circ}\right)$ & Beda Tinggi (m) \\
\hline 1 & Datar/Hampir Datar & $0-2$ & $0-2$ & $<5$ \\
2 & Bergelombang Landai & $3-7$ & $2-4$ & $5-25$ \\
3 & Bergelombang Miring & $8-13$ & $4-8$ & $25-75$ \\
4 & Berbukit Bergelombang & $14-20$ & $8-16$ & $50-200$ \\
5 & Berbukit Terjal & $21-55$ & $16-35$ & $200-500$ \\
6 & Pegunungan Sangat Terjal & $56-140$ & $35-55$ & $500-1.000$ \\
\hline
\end{tabular}

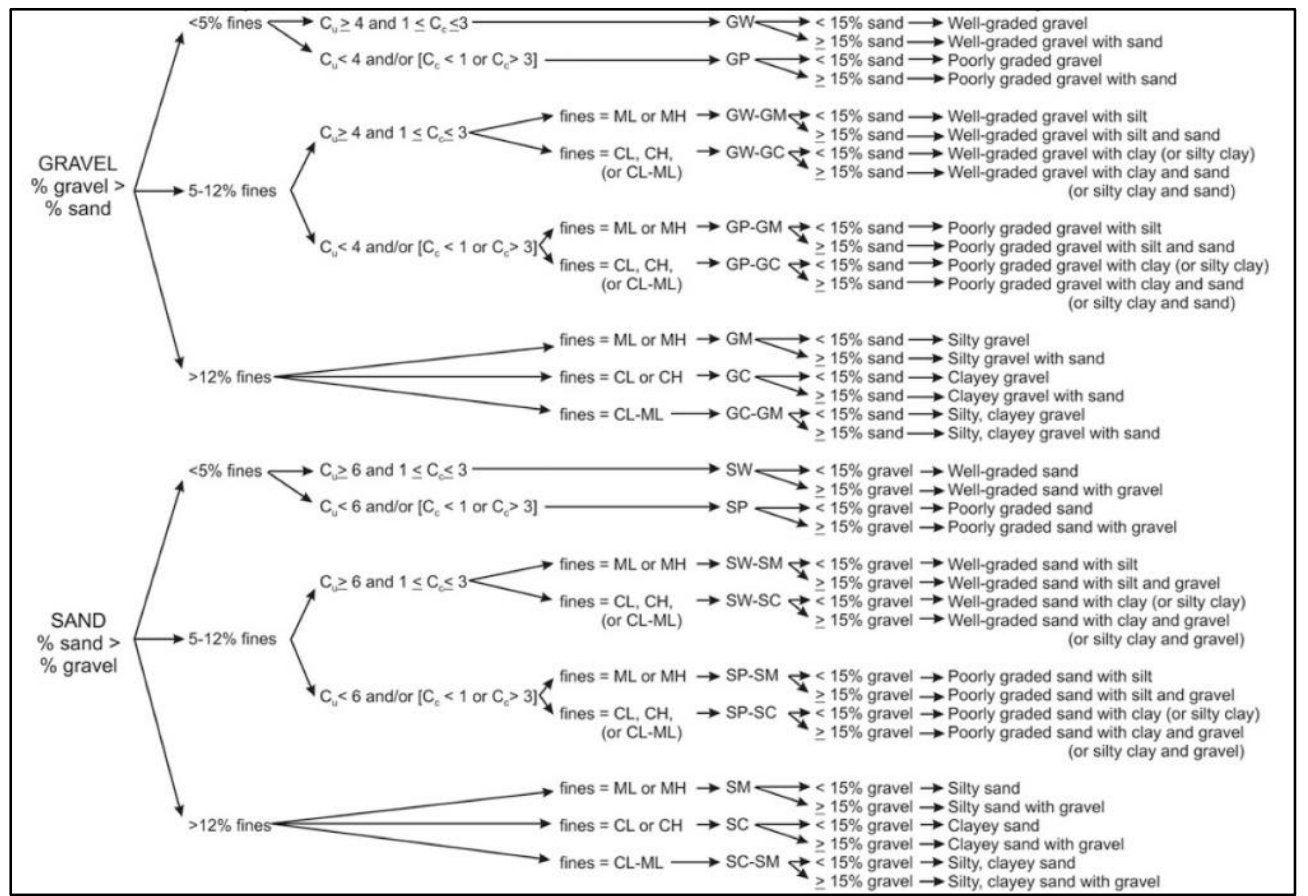

Gambar 3. Klasifikasi USCS untuk tanah berbutir kasar (ASTM D2487, 2000) 


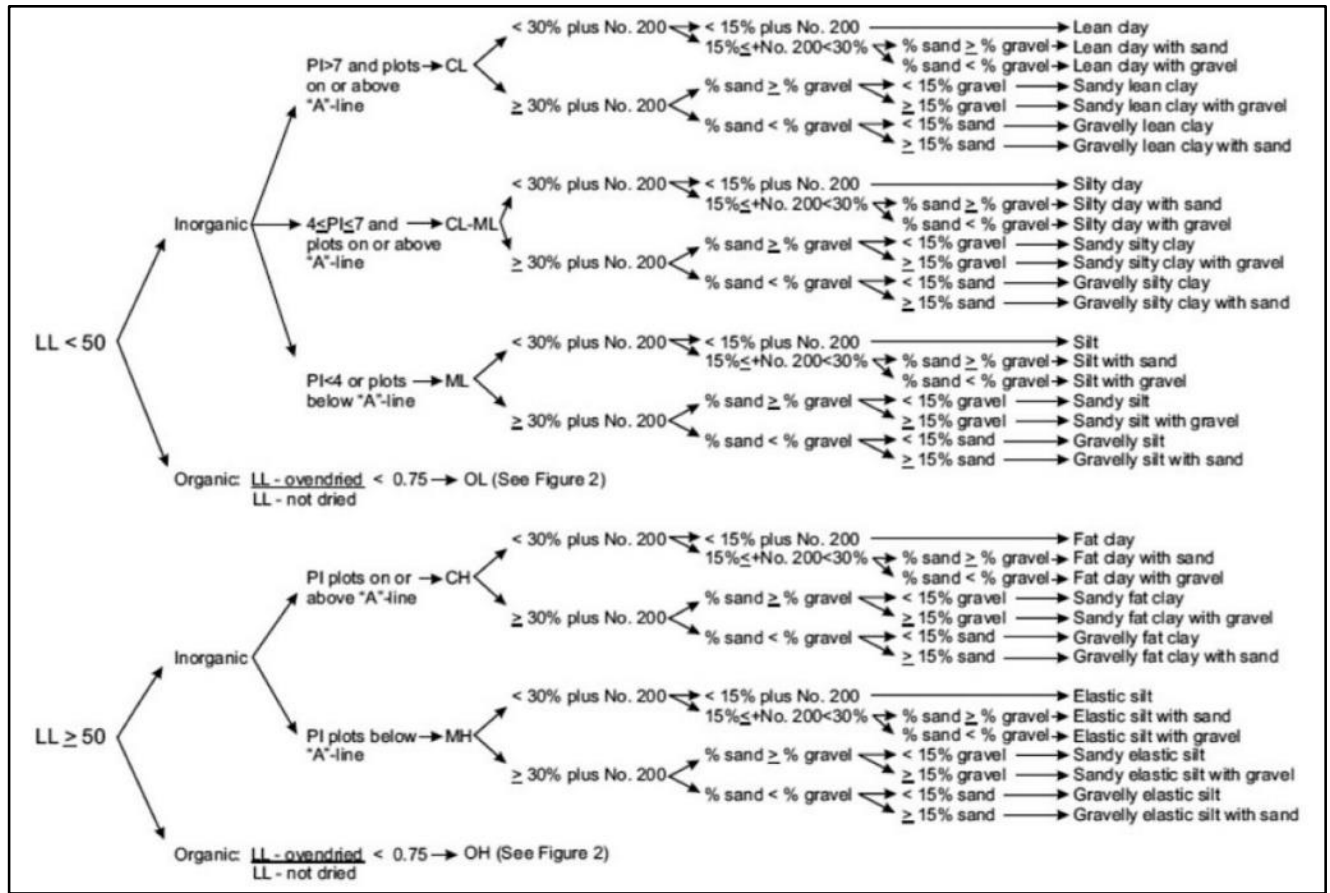

Gambar 4. Klasifikasi USCS untuk tanah berbutir halus (ASTM D2487, 2000)

Tabel 2. Skor parameter zona rawan gempabumi (Modifikasi Permen PU, 2007)

\begin{tabular}{|c|c|c|c|c|c|c|c|}
\hline No & $\begin{array}{l}\text { Informasi } \\
\text { Geologi }\end{array}$ & \multicolumn{3}{|c|}{ Kelas Informasi } & Nilai & Bobot & Skor \\
\hline \multirow[t]{4}{*}{1} & $\begin{array}{l}\text { Geologi } \\
\text { (sifat fisik }\end{array}$ & \multicolumn{3}{|c|}{$\begin{array}{l}\text { Andesit, granit, diorit, malihan, breksi vulkanik, } \\
\text { aglomerat, breksi sedimen, konglomerat }\end{array}$} & 1 & 3 & 3 \\
\hline & $\begin{array}{l}\text { dan } \\
\text { keteknikan }\end{array}$ & \multicolumn{3}{|c|}{$\begin{array}{l}\text { Batupasir, tufa kasar, batulanau, arkose, } \\
\text { grevwacke, batugamping }\end{array}$} & 2 & & 6 \\
\hline & batuan) & \multicolumn{3}{|c|}{$\begin{array}{l}\text { greywacke, batugamping } \\
\text { Pasir, lanau, batulempung, napal, tufa halus, } \\
\text { gambut }\end{array}$} & 3 & & 9 \\
\hline & & \multicolumn{3}{|c|}{ Lempung, lumpur, lempung organik, gambut } & 4 & & 12 \\
\hline \multirow[t]{4}{*}{2} & Kemiringan & \multicolumn{3}{|c|}{ Datar - Landai $(0-7 \%)$} & 1 & 3 & 3 \\
\hline & Lereng & \multicolumn{3}{|c|}{ Miring - Agak Curam $(7-30 \%)$} & 2 & & 6 \\
\hline & & \multirow{2}{*}{\multicolumn{3}{|c|}{$\begin{array}{l}\text { Curam - Sangat Curam }(30-140 \%) \\
\text { Terjal }(>140 \%)\end{array}$}} & 3 & & 9 \\
\hline & & & & & 4 & & 12 \\
\hline \multirow[t]{5}{*}{3} & Kegempaan & MMI & $\alpha$ & Richter & & & \\
\hline & & I, II, III, IV, V & $<0,05 \mathrm{~g}$ & $<5$ & 1 & 5 & 5 \\
\hline & & VI, VII & $0,05-0,15 \mathrm{~g}$ & $5-6$ & 2 & & 10 \\
\hline & & VIII & $0,15-0,3 \mathrm{~g}$ & $6-6,5$ & 3 & & 15 \\
\hline & & IX, X, XI, XII & $>0,3 \mathrm{~g}$ & $>6,5$ & 4 & & 20 \\
\hline \multirow[t]{3}{*}{4} & Struktur & \multicolumn{3}{|l|}{ Jauh dari zona se } & 1 & 4 & 4 \\
\hline & Geologi & \multicolumn{3}{|c|}{$\begin{array}{l}\text { Dekat dengan zona sesar }(100-1000 \mathrm{~m} \text { dari } \\
\text { zona sesar) }\end{array}$} & 2 & & 8 \\
\hline & & \multicolumn{3}{|c|}{ Pada zona sesar (<100 m dari zona sesar) } & 4 & & 16 \\
\hline
\end{tabular}

Tabel 3. Skor tipologi kawasan rawan gempabumi (Modifikasi Permen PU, 2007)

\begin{tabular}{ccc}
\hline Kestabilan & Skor hasil overlay & Tipologi \\
\hline \multirow{2}{*}{ Stabil } & $31-35$ & $\mathrm{~A}$ \\
& $36-40$ & $\mathrm{~B}$ \\
Kurang Stabil & $41-45$ & $\mathrm{C}$ \\
& $46-50$ & $\mathrm{D}$ \\
Tidak Stabil & $51-55$ & $\mathrm{E}$ \\
& $57-60$ & $\mathrm{~F}$ \\
\hline
\end{tabular}


Tabel 4. Skor parameter kemiringan lereng (Modifikasi Matondang, 2013 dalam Nugroho, 2013)

\begin{tabular}{cllccc} 
No & Kemiringan $(\%)$ & Deskripsi & Nilai & Bobot & Skor \\
\hline 1 & $0-8$ & Datar & 5 & 5 & 25 \\
2 & $>8-15$ & Landai & 4 & 5 & 20 \\
3 & $>15-25$ & Agak Curam & 3 & 5 & 15 \\
4 & $>25-45$ & Curam & 2 & 5 & 10 \\
5 & $>45$ & Sangat Curam & 1 & 5 & 5 \\
\hline
\end{tabular}

Tabel 5. Skor parameter jenis tanah (Modifikasi Matondang, 2013 dalam Nugroho, 2013)

\begin{tabular}{llccc} 
No & Jenis tanah & Nilai & Bobot & Skor \\
\hline 1 & Aluvial & 5 & 3 & 15 \\
2 & Latosol & 4 & 3 & 12 \\
3 & Regosol & 3 & 3 & 9 \\
4 & Andosol coklat & 2 & 3 & 6 \\
5 & Andosol hitam & 1 & 3 & 3 \\
\hline
\end{tabular}

Tabel 6. Skor parameter curah hujan (Modifikasi Matondang, 2013 dalam Nugroho, 2013)

\begin{tabular}{cllccc}
\hline No & $\begin{array}{l}\text { Nilai “hujan infiltrasi” } \\
\text { (mm.hari/tahun) }\end{array}$ & Deskripsi & Nilai & Bobot & Skor \\
\hline 1 & $<1.500$ & Rendah & 1 & 2 & 2 \\
2 & $1.500-3.000$ & Sedang & 2 & 2 & 4 \\
3 & $3.000-4.500$ & Cukup besar & 3 & 2 & 6 \\
4 & $4.500-5.000$ & Besar & 4 & 2 & 8 \\
5 & $>5.500$ & Sangat besar & 5 & 2 & 10 \\
\hline
\end{tabular}

Tabel 7. Skor parameter penggunaan lahan (Modifikasi Matondang, 2013 dalam Nugroho, 2013)

\begin{tabular}{clccc} 
No & Jenis tanah & Nilai & Bobot & Skor \\
\hline 1 & Pemukiman, sawah, rawa & 5 & 2 & 10 \\
2 & Tegalan, ladang & 4 & 2 & 8 \\
3 & Semak, padang rumput & 3 & 2 & 6 \\
4 & Hutan, perkebunan & 2 & 2 & 4 \\
5 & Pasir & 1 & 2 & 2 \\
\hline
\end{tabular}

Tabel 8. Skor parameter kerapatan sungai (Modifikasi Matondang, 2013 dalam Nugroho, 2013)

\begin{tabular}{clccc} 
No & Kerapatan Aliran $\left(\mathrm{Km} / \mathrm{Km}^{2}\right)$ & Nilai & Bobot & Skor \\
\hline 1 & $<0,62$ & 5 & 3 & 15 \\
2 & $0,62-1,44$ & 4 & 3 & 12 \\
3 & $1,45-2,27$ & 3 & 3 & 9 \\
4 & $2,28-3,1$ & 2 & 3 & 6 \\
5 & $>3,1$ & 1 & 3 & 3 \\
\hline
\end{tabular}

di mana: $\mathrm{i}=$ lebar interval; $\mathrm{R}=$ selisih skor maksimum dan minimum; dan $\mathrm{N}=$ jumlah kelas kerawanan 


\section{METODOLOGI}

Penelitian diawali dengan dilakukan studi pustaka untuk mengumpulkan data sekunder yang dibutuhkan dalam penelitian serta mempersiapkan peralatan dan bahan yang dibutuhkan saat di lapangan dan pembuatan peta topografi atau basemap daerah penelitian. Data sekunder yang digunakan meliputi data digital elevation model (DEM) dari sumber DEMNAS dengan resolusi $4 \mathrm{~m}$, peta geologi regional lembar Kebumen, peta rupa bumi Indonesia lembar Ngombol kode 1408-124, dan data curah hujan darti tahun 2008 hingga 2017 untuk wilayah Kecamatan Ngombol. Tahap berikutnya berupa pemetaan yang dilakukan untuk mengetahui persebaran keterdapatan tanah pada daerah penelitian. Dari pemetaan yang dilakukan, pengambilan sampel tanah dan pendeskripsian lanjut dilakukan untuk menentukan jenis tanah secara spesifik. Sampel tanah yang sudah diambil sejumlah 12 unit kemudian diayak untuk mengetahui distribusi ukuran partikel tanah dengan menggunakan alat sieve nomor 4, 6, 10, 20, 40, 60, 100, 200 dan pan.

Setiap parameter penentu zona rawan bencana diberi nilai (value), kemudian dikali dengan bobot untuk mendapatkan skor. Skor yang dihasilkan dari setiap parameter penetuan zona rawan bencana banjir maupun gempa akan diakumulasikan. Parameter yang terkait dengan kelerengan, acuan penggolongan nilai dan karakterisasi jenis bentuklahannya didasarkan pada klasifikasi van Zuidam (1983) yang dapat dilihat pada Tabel 1 dan diolah dengan mengekstrak data DEM dan diinterpolasi dalam perangkat lunak Arc Map 10.3 dengan fitur Slope. Pengakumulasian skor menggunakan fitur Raster Calculator pada Arc Map 10.3. Nilai baru yang didapatkan dari overlay skor tiap parameter akan diklasifikasi ulang untuk menentukan kelas-kelas zona rawan banjir maupun gempabumi. Zona rawan banjir akan terbagi menjadi 3 kelas yaitu zona tidak rawan, zona cukup rawan dan zona sangat rawan. Pembagian tersebut didapatkan dari kalkulasi interval yang diperoleh dengan memakai Persamaan 1, dengan asumsi bahwa zonasi kerawanan dibagi atas 3 unit. Zona rawan gempabumi lebih lanjut terbagi dalam 6 kelas: Tipologi A hingga Tipologi F (Tabel 3).

\section{HASIL PENELITIAN}

Geologi Daerah Penelitian

Satuan litologi yang terdapat di daerah penelitian adalah berupa endapan aluvial dan endapan pantai. Hubungan stratigrafi antara kedua endapan adalah endapan aluvial berada di atas endapan pantai. Tidak ditemukannya struktur geologi yang berkembang di daerah penelitian. Persebaran dari endapan aluvial dan endapan pantai pada Kecamatan Ngombol dapat dilihat pada Gambar 5, sedangkan untuk perbedaan kenampakan serta deskripsi antara endapan aluvial dan endapan pantai secara visual di lapangan pada saaat dilakukan tinjauan lapangan dapat dilihat pada Gambar 6.

\section{Geomorfologi Daerah Penelitian}

Hasil dari analisis geomorfologi dalam bentuk peta geomorfologi didapatkan 2 satuan bentuk lahan, yaitu satuan bentuk lahan dataran denudasional dan satuan bentuk lahan pantai (van Zuidam, 1983) (Gambar 7). Satuan dataran denudasional tergolong ke dalam bentuk lahan denudasional. Satuan dataran terbentuk akibat proses denudasional. Satuan dataran menempati kurang lebih $90 \%$ wilayah Kecamatan Ngombol. Penentuan nama satuan tersebut didasarkan atas adanya kenampakan umum morfologi yang datar, topografi landai hingga sedikit bergelombang, serta elevasi rendah dengan elevasi terendah sebesar $10 \mathrm{~m}$ dan eleveasi tertinggi sebesar 15, beda tinggi $5 \mathrm{~m}$. Litologi yang terdapat pada satuan ini adalah endapan aluvial. Tata guna lahan sebagian besar merupakan pemukiman dan sawah, beberapa digunakan sebagai kebun dan ladang. Bencana kebumian yang berpotensi terjadi adalah banjir dikarenakan daerah yang relatif datar.

Satuan pantai menempati sekitar 10\% keseluruhan wilayah Kecamatan Ngombol. Penentuan nama satuan tersebut didasarkan atas adanya endapan pantai. Satuan ini tersebar di bagian selatan Kecamatan Ngombol mengikuti garis pantai, meliputi Desa Ngentak, Desa Girirejo, Desa Wero, Desa Pagak, Desa Malang dan Desa Keburuhan. Kenampakan umum morfologi yang hampir datar dan lereng yang landai, dengan beda tinggi sebesar $5 \mathrm{~m}$. Bencana yang berpotensi terjadi berupa banjir saat pasang. 


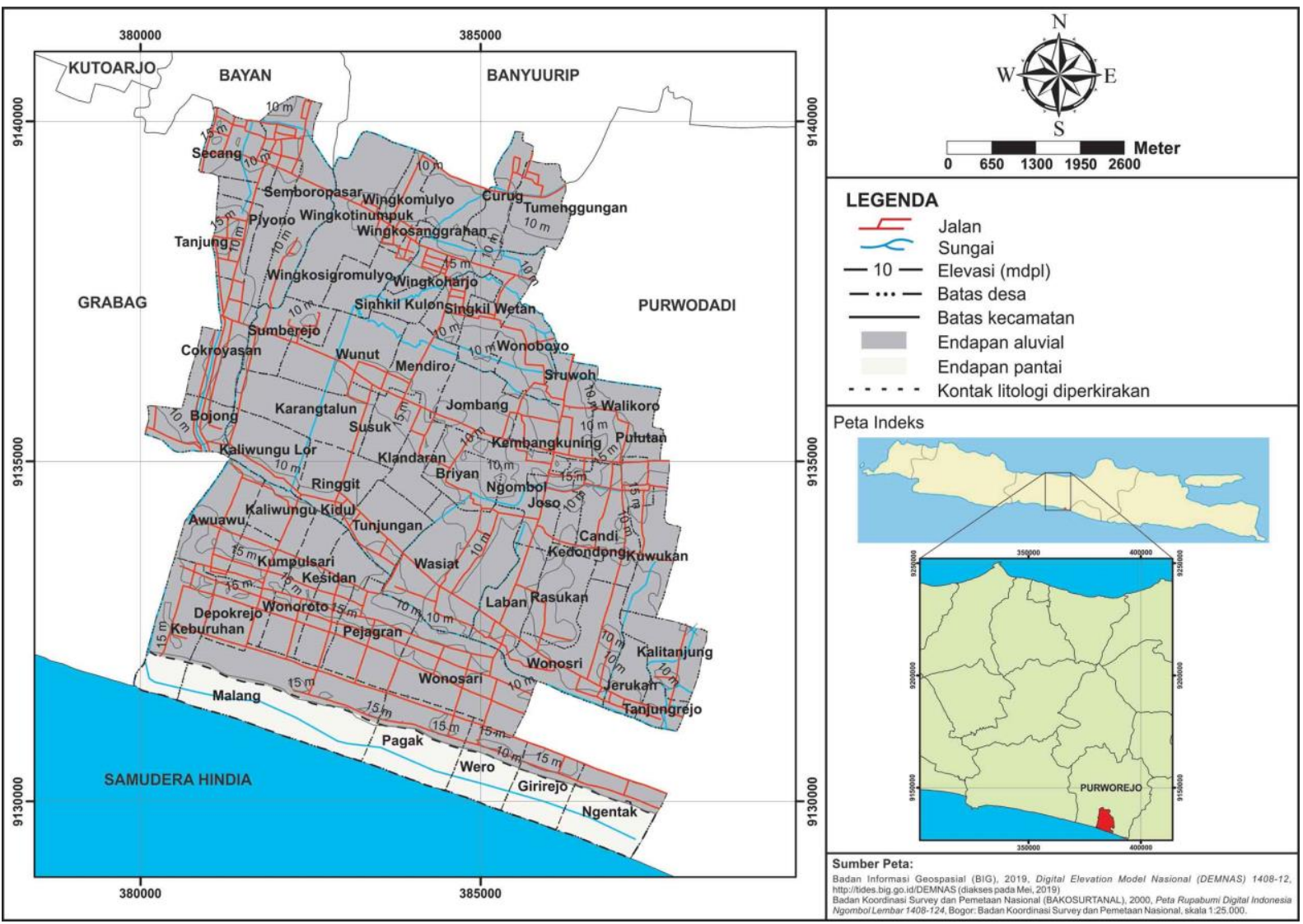

Gambar 5. Peta geologi Kecamatan Ngombol.

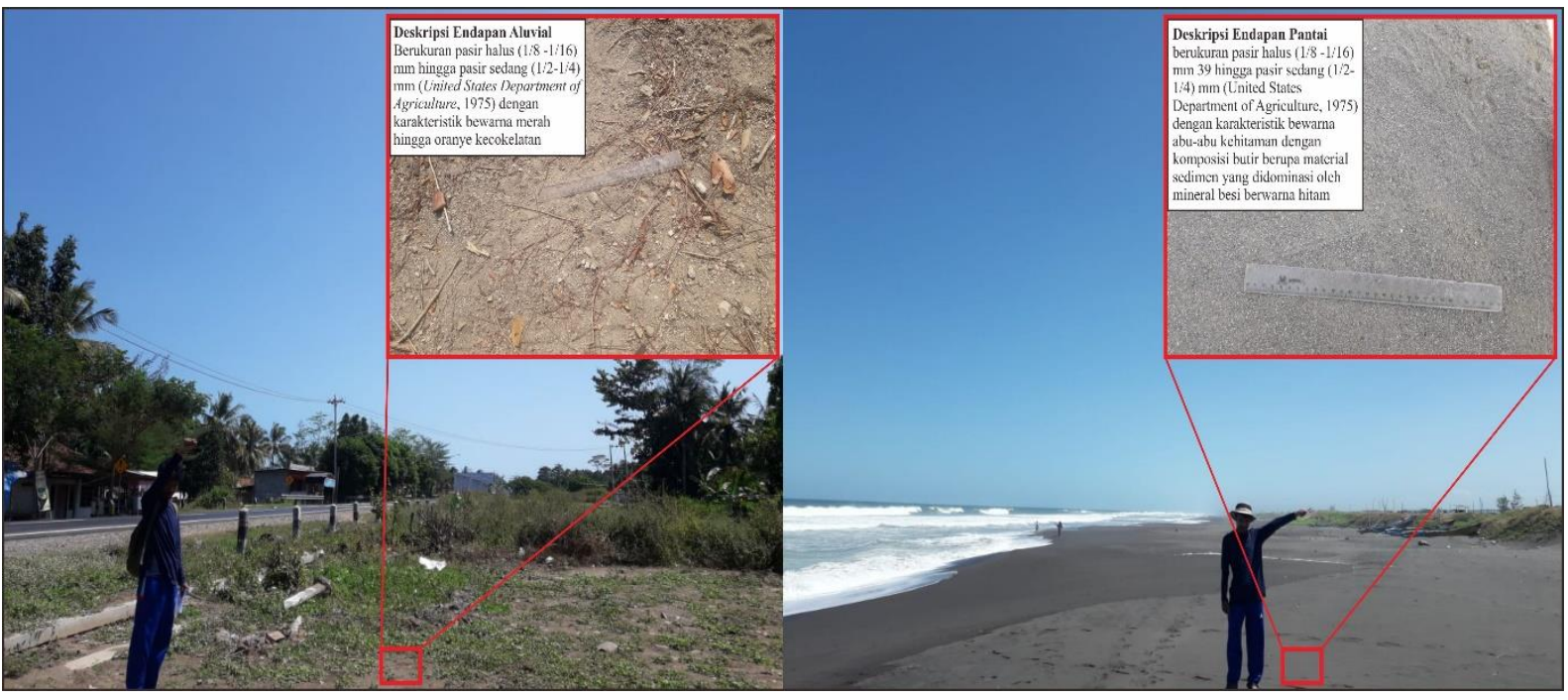

Gambar 6. Kenampakan dan deskripsi lapangan dari endapan aluvial (kiri) dan endapan pantai (kanan) 


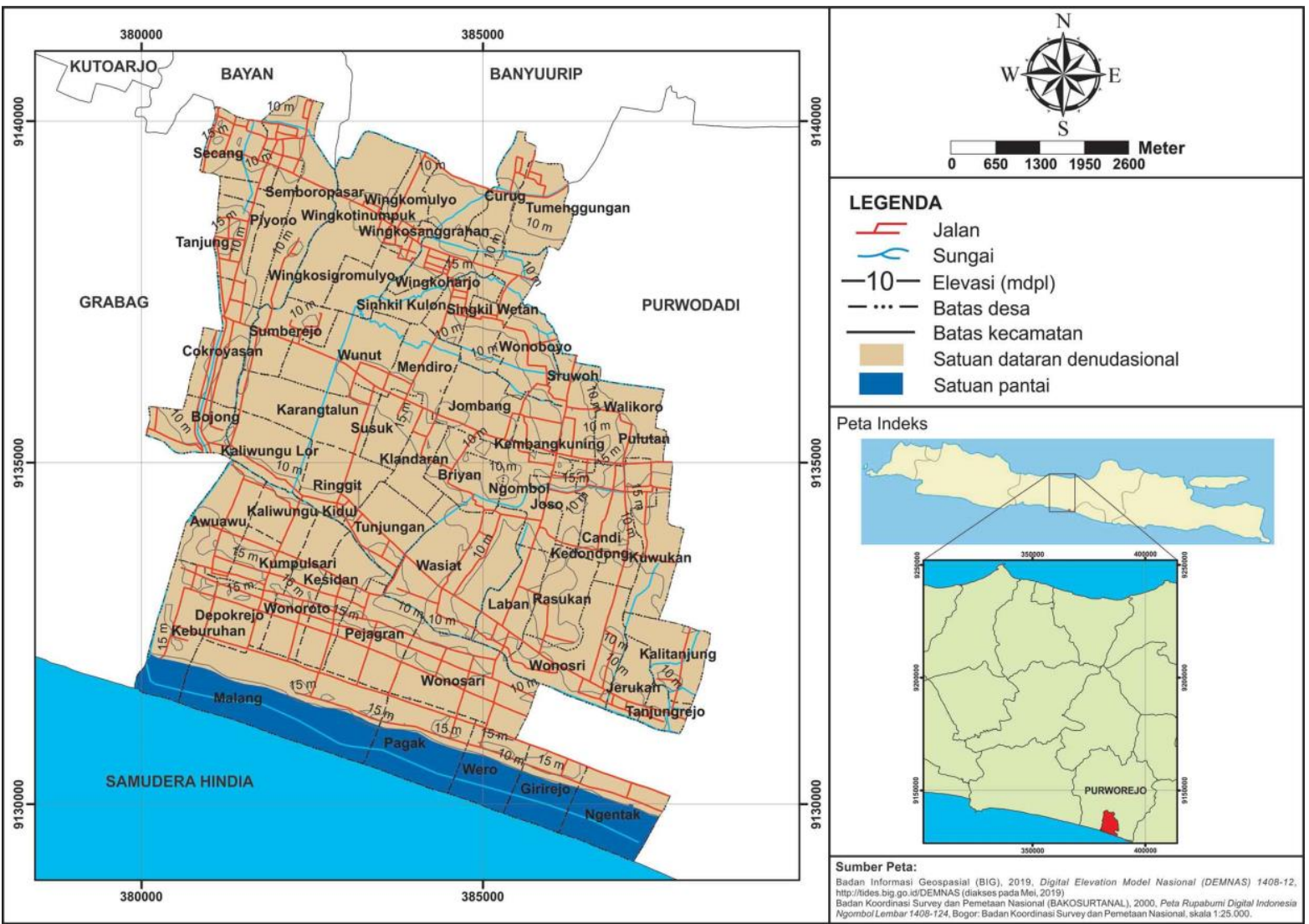

Gambar 7. Peta geomorfologi Kecataman Ngombol.

\section{Parameter Zona Rawan Gempa}

1) Geologi

Pengambilan sampel tanah dilakukan pada pemetaan geologi yang tersebar pada 12 titik stasiun pengamatan (STA) di Kecamatan Ngombol (Gambar 8). Dari hasil pengayakan 12 sampel tanah didapatkan hasil tanah tergolong ke kategori sand (Tabel 9).

2) Kemiringan lereng

Kecamatan Ngombol yang merupakan daerah pesisir, di mana berdasarkan analisis kelerengan dari data DEM secara dominan mempunyai kemiringan lereng yang tergolong datar hingga agak curam dengan persentase kemiringan 0 hingga 30\% walaupun di sebagian tempat tergolong curam dengan persentase kemiringan $40 \%$ hingga mendekati 70\% (Modifikasi Matondang, 2013 dalam Nugroho, 2013).

3) Kegempaan

Data kegempaan Kecamatan Ngombol menggunakan data guncangan gempa di Kota Water pada 10 Agustus 2019 yang terasa hingga Purworejo yaitu sebesar II MMI. Mengacu pada klasifikasi Peraturan Menteri Pekerjaan Umum (2007), intensitas gempa sebesar II MMI mempunyai nilai PGA kurang dari $0,05 \mathrm{~g}$ dan memiliki nilai 1 dalam analisis scoring penentuan zona rawan bencana gempabumi.

4) Stuktur geologi

Episenter gempabumi Bantul yang terjadi pada 10 Agustus 2019 berlokasi di laut sejauh $113 \mathrm{~km}$ arah selatan Kota Wates, Kabupaten Kulon Progo pada kedalaman $71 \mathrm{~km}$ yang disebabkan adanya sesar naik (BMKG, 2019). episenter gempabumi Purworejo yang terjadi pada 18 Juli 2016 terletak $18 \mathrm{~km}$ dari arah barat laut Purworejo pada kedalaman $13 \mathrm{~km}$ (BMKG, 2016 dalam Wibowo dan Nurhaci, 2017). Kecamatan Ngombol berada kurang lebih $27 \mathrm{~km}$ di arah selatan dari episenter gempa Purworejo.

Kecamatan Ngombol berpotensi terkena bencana gempabumi yang berpusat di darat maupun di laut berdasarkan data gempa Bantul tahun 2019 dan gempa Purworejo tahun 2016. Jarak yang cukup jauh dari episenter kedua gempa tersebut, Kecamatan Ngombol berada jauh zona sesar, dan masuk sebagai zona stabil untuk bencana gempabumi (Permen PU, 2007). 


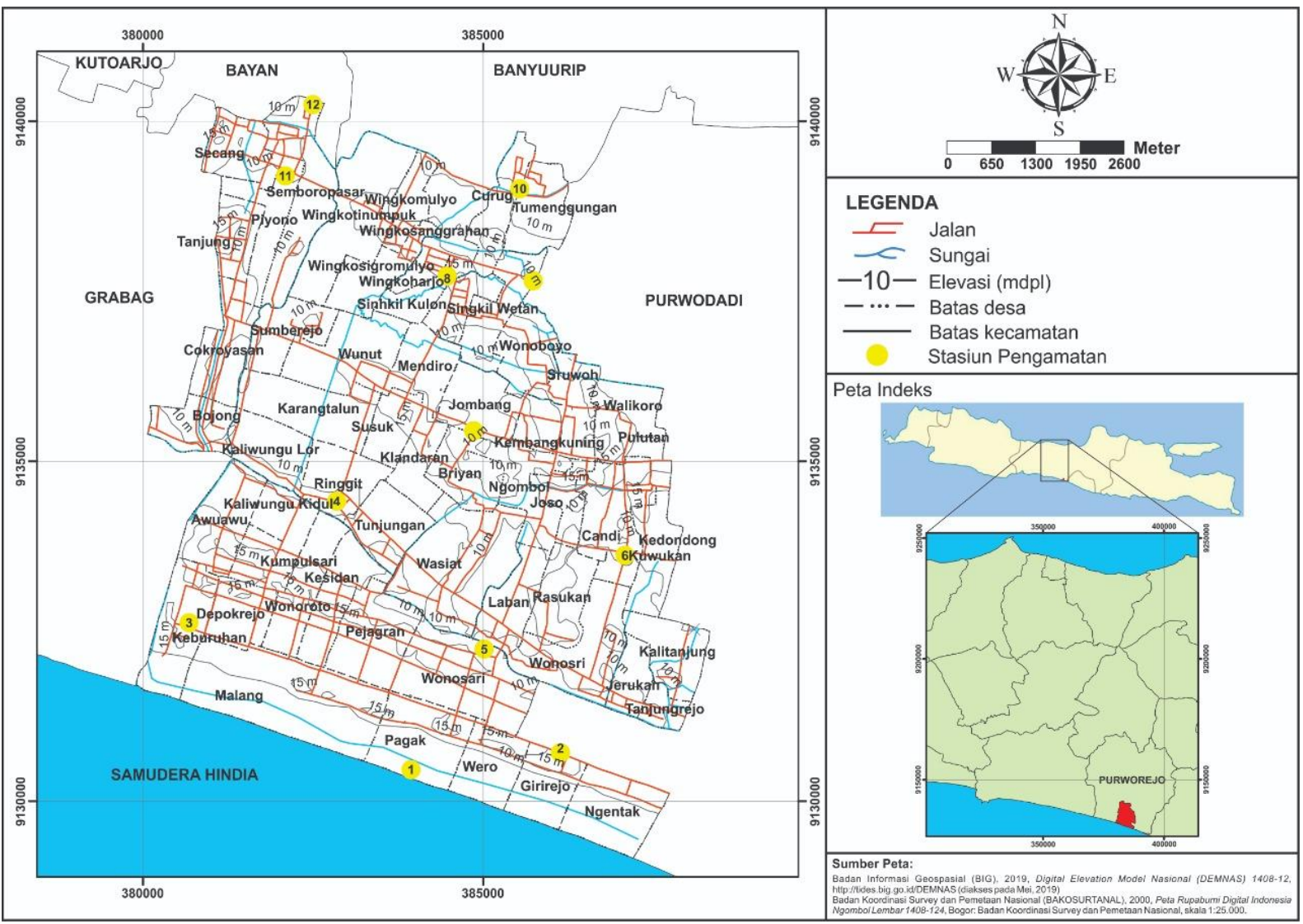

Gambar 8. Peta sebaran titik pengambilan sampel tanah di Kecataman Ngombol.

Tabel 9. Hasil pengayakan 12 sampel tanah

\begin{tabular}{cccc}
\hline No. Sampel & $\begin{array}{c}\text { Tertahan Sieve 4 } \\
(\%)\end{array}$ & $\begin{array}{c}\text { Lolos Sieve 200 } \\
(\%)\end{array}$ & $\begin{array}{c}\text { Kategori } \\
\text { (ASTM Standard D2487, 2000) }\end{array}$ \\
\hline 1 & 0 & 1,28 & Sand \\
2 & 1,28 & 27,94 & Sand \\
3 & 0,84 & 23,8 & Sand \\
4 & 0 & 21,62 & Sand \\
5 & 7,56 & 22,12 & Sand \\
6 & 10,64 & 10,24 & Sand \\
7 & 5,64 & 16,99 & Sand \\
8 & 5,57 & 9,52 & Sand \\
9 & 10,93 & 11,27 & Sand \\
10 & 1,95 & 18,75 & Sand \\
11 & 3,79 & 13,31 & Sand \\
12 & 7,56 & 7,88 & Sand \\
\hline
\end{tabular}

\section{Parameter Zona Rawan Gempa}

1) Kemiringan lereng

Kecamatan Ngombol yang merupakan daerah pesisir, secara dominan mempunyai kemiringan lereng yang tergolong datar hingga landai dengan persentase kemiringan 0 hingga $15 \%$.

2) Jenis tanah

Tanah yang menyusun Kecamatan Ngombol merupakan tanah yang terbentuk dari hasil endapan atau dapat dikatakan sebagai tanah aluvial (Dudal dan Soepraptohardjo, 1957). Hasil pemetaan geologi pada Kecamatan Ngombol dijabarkan pada Tabel 10. Single grained yang dimaksud dalam Tabel 10 adalah kondisi tanah yang saling lepas, sedangkan massive mengacu pada kondisi yang kompak. Parameter penentuan apakah jenis tanah masuk dalam kategori pasir dan pasir lempung mengacu 
pada hasil proses pengayakan sampel tanah, sedangkan untuk penentuan poin warna adalah gabungan dari intepretasi lapangan dan pencocokan pada referensi warna menurut Munsel Color (1994).

3) Curah hujan

Sejak tahun 2008 hingga 2017, didapatkan rata-rata nilai hujan infiltrasi pada Kecamatan Ngombol sebesar 3.245,93 mm.hari/tahun (Tabel 11). Berdasarkan Nugroho (2013), rata-rata nilai hujan hujan di Kecamatan Ngombol tergolong dalam kelas cukup besar (Tabel 6).

4) Penggunaan lahan

Kecamatan Ngombol secara menyeluruh tersusun atas 7 tutupan lahan yaitu semak belukar, pemukiman, kebun, ladang, sawah, dan pasir pantai pada bagian selatan. Persebaran sawah mendominasi diikuti dengan pemukiman warga yang tersebar pada wilayah Kecamatan Ngombol.

5) Kerapatan Sungai

Kecamatan Ngombol secara dominan mempunyai kerapatan sungai $>3,1 \mathrm{~km} / \mathrm{km}^{2}$.

\section{PEMBAHASAN}

\section{Overlay Parameter}

1) Overlay parameter zona rawan gempa

Hasil penilaian dari tiap parameter zona rawan gempabumi pada Kecamatan Ngombol dapat dilihat pada Tabel 12. Berdasarkan hasil overlay diperoleh skor dengan nilai 21, 24 dan 27 yang tergolong ke dalam tipologi A (Kementerian Pekerjaan Umum, 2007). Tipologi A merupakan daerah yang mengalami kerusakan lebih kecil saat terkena getaran gempabumi. Persebaran tipologi kawasan rawan gempabumi dapat dilihat pada Gambar 9.

Tabel 10. Sifat fisik tanah daerah penelitian

\begin{tabular}{cccc}
\hline Stasiun Pengamatan & Struktur (Foth, 1990) & Tekstur (Hanafiah, 2005) & Warna (Munsell Color, 1994) \\
\hline 1 & single grained & Pasir & 2,5 YR 7/1 \\
2 & massive & Pasir berlempung & 7,5 YR 8/3 \\
3 & massive & Pasir berlempung & 7,5 YR 8/3 \\
4 & massive & Pasir berlempung & 7,5 YR 7/2 \\
5 & massive & Pasir berlempung & 7,5 YR 7/3 \\
6 & massive & Pasir & 7,5 YR 6/4 \\
7 & massive & Pasir berlempung & 7,5 YR 4/6 \\
8 & massive & Pasir & 7,5 YR 8/1 \\
9 & massive & Pasir berlempung & 7,5 YR 6/1 \\
10 & massive & Pasir berlempung & 7,5 YR 7/1 \\
11 & massive & Pasir & 7,5 YR 8/2 \\
12 & massive & Pasir berlempung & 7,5 YR 8/2 \\
\hline
\end{tabular}

Tabel 11. Rata-rata curah hujan Kecamatan Ngombol dari tahun 2008-2017 (Modifikasi BPS Kabupaten Purworejo tahun 2009-2018)

\begin{tabular}{ccccccccccc}
\hline & 2008 & 2009 & 2010 & 2011 & 2012 & 2013 & 2014 & 2015 & 2016 & 2017 \\
\hline Nilai faktor & & & & 2978, & 1991, & 3794, & 2937, & 2844, & 6926, & 4906,5 \\
"hujan infiltrasi" \\
$\begin{array}{c}\text { (mm.hari/tahun) } \\
\text { Rata-rata }\end{array}$
\end{tabular}

Tabel 12. Skor parameter zona rawan gempabumi pada Kecamatan Ngombol (Modifikasi Permen PU, 2007)

\begin{tabular}{cllcc}
\hline No & Informasi Geologi & Kelas Informasi & Skor \\
\hline 1 & $\begin{array}{l}\text { Geologi (sifat fisik dan } \\
\text { keteknikan batuan) }\end{array}$ & Pasir & 9 \\
2 & Kemiringan Lereng & Datar - Landai $(0-7 \%)$ & 3 \\
& & Miring - Agak Curam $(7-30 \%)$ & 6 \\
& & Curam - Sangat Curam $(30-140 \%)$ & 9 \\
3 & Kegempaan & MMI & Richter & 5 \\
& & I, II, III, IV, V & $<5,05 \mathrm{~g}$ & 4 \\
4 & Struktur Geologi & Jauh dari zona sesar & & 4 \\
\hline
\end{tabular}




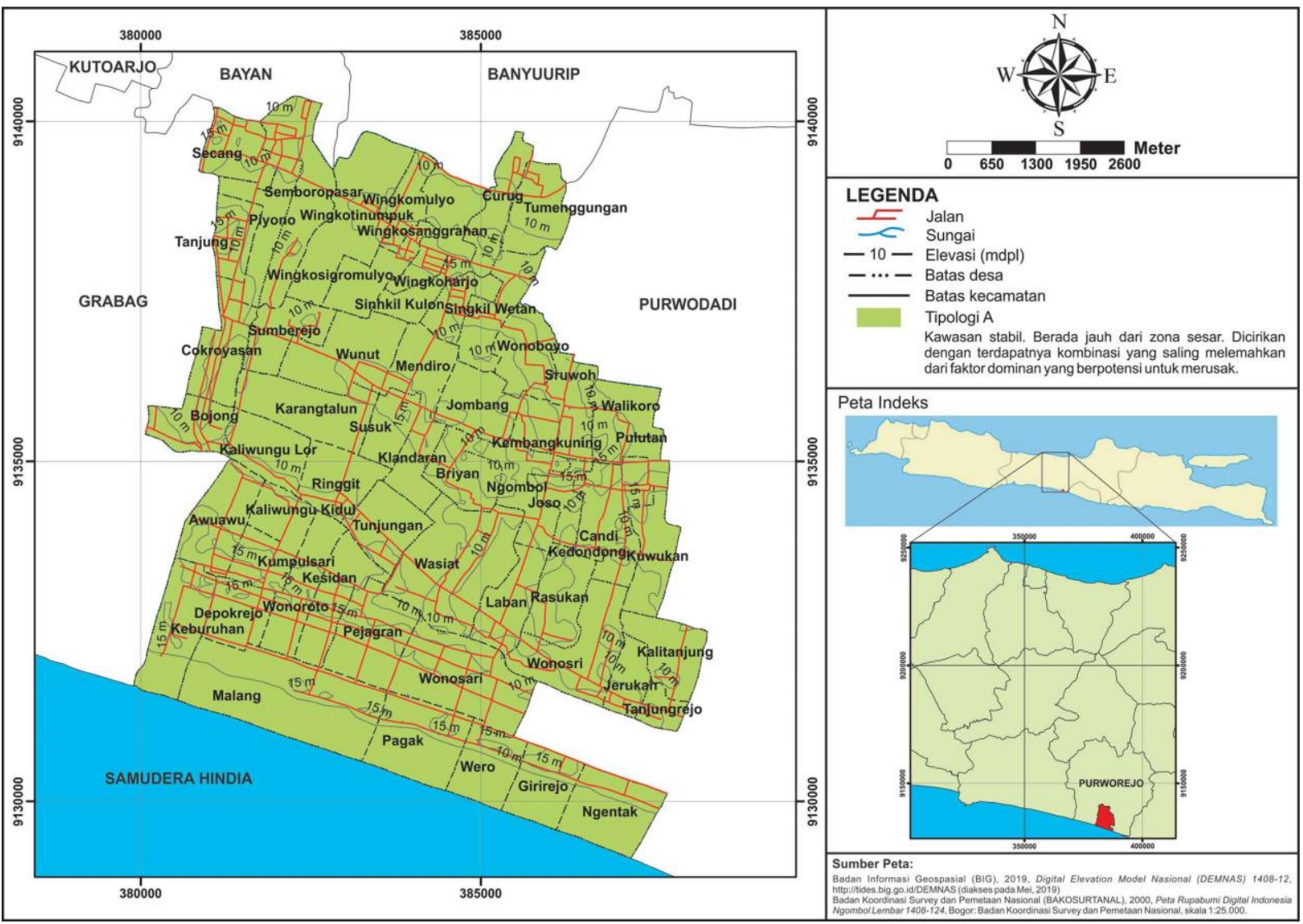

Gambar 9. Peta zona rawan bencana gempabumi Kecamatan Ngombol

Tabel 13. Skor parameter zona rawan banjir pada Kecamatan Ngombol (Modifikasi Nugroho, 2013)

\begin{tabular}{|c|c|c|c|c|c|}
\hline No. & Parameter & Hasil & Bobot & Nilai & Skor \\
\hline \multirow[t]{5}{*}{1.} & Kemiringan lereng & Datar & 5 & 5 & 25 \\
\hline & & Landai & & 4 & 20 \\
\hline & & Agak Curam & & 3 & 15 \\
\hline & & Curam & & 2 & 10 \\
\hline & & Sangat Curam & & 1 & 5 \\
\hline 2 & Jenis tanah & Aluvial & 5 & 3 & 15 \\
\hline 3 & Curah hujan & $3.000-4.500$ & 2 & 3 & 6 \\
\hline \multirow[t]{5}{*}{4} & Penggunaan lahan & Pemukiman, sawah, rawa & 2 & 5 & 10 \\
\hline & & Tegalan, ladang & & 4 & 8 \\
\hline & & Semak, padang rumput & & 3 & 6 \\
\hline & & Hutan, perkebunan & & 2 & 4 \\
\hline & & Pasir & & 1 & 2 \\
\hline \multirow[t]{5}{*}{5} & Rapat sungai & $<0,62 \mathrm{Km} / \mathrm{Km}^{2}$ & 3 & 5 & 15 \\
\hline & & $0,62-1,44 \mathrm{Km} / \mathrm{Km}^{2}$ & & 4 & 12 \\
\hline & & $1,45-2,27 \mathrm{Km} / \mathrm{Km}^{2}$ & & 3 & 9 \\
\hline & & $2,28-3,1 \mathrm{Km} / \mathrm{Km}^{2}$ & & 2 & 6 \\
\hline & & $>3,1 \mathrm{Km} / \mathrm{Km}^{2}$ & & 1 & 3 \\
\hline
\end{tabular}

\section{2) Overlay parameter zona rawan banjir}

Hasil scoring dari parameter-parameter zona rawan banjir pada daerah penelitian dapat dilihat pada Tabel 13. Skor parameter zona rawan banjir pada daerah penelitian memiliki rentang nilai mulai dari 33 hingga 71 . Persebaran zona rawan banjir dapat dilihat pada Gambar 10. Mengacu pada rumus Persamaan 1, diperoleh interval nilai 12,7 untuk acuan 3 jenis zonasi. pengelompokan zona rawan banjir meliputi: zona tidak rawan (33$45,7)$; zona cukup rawan $(45,7-58,4)$; dan zona sangat rawan $(58,4-71)$. 


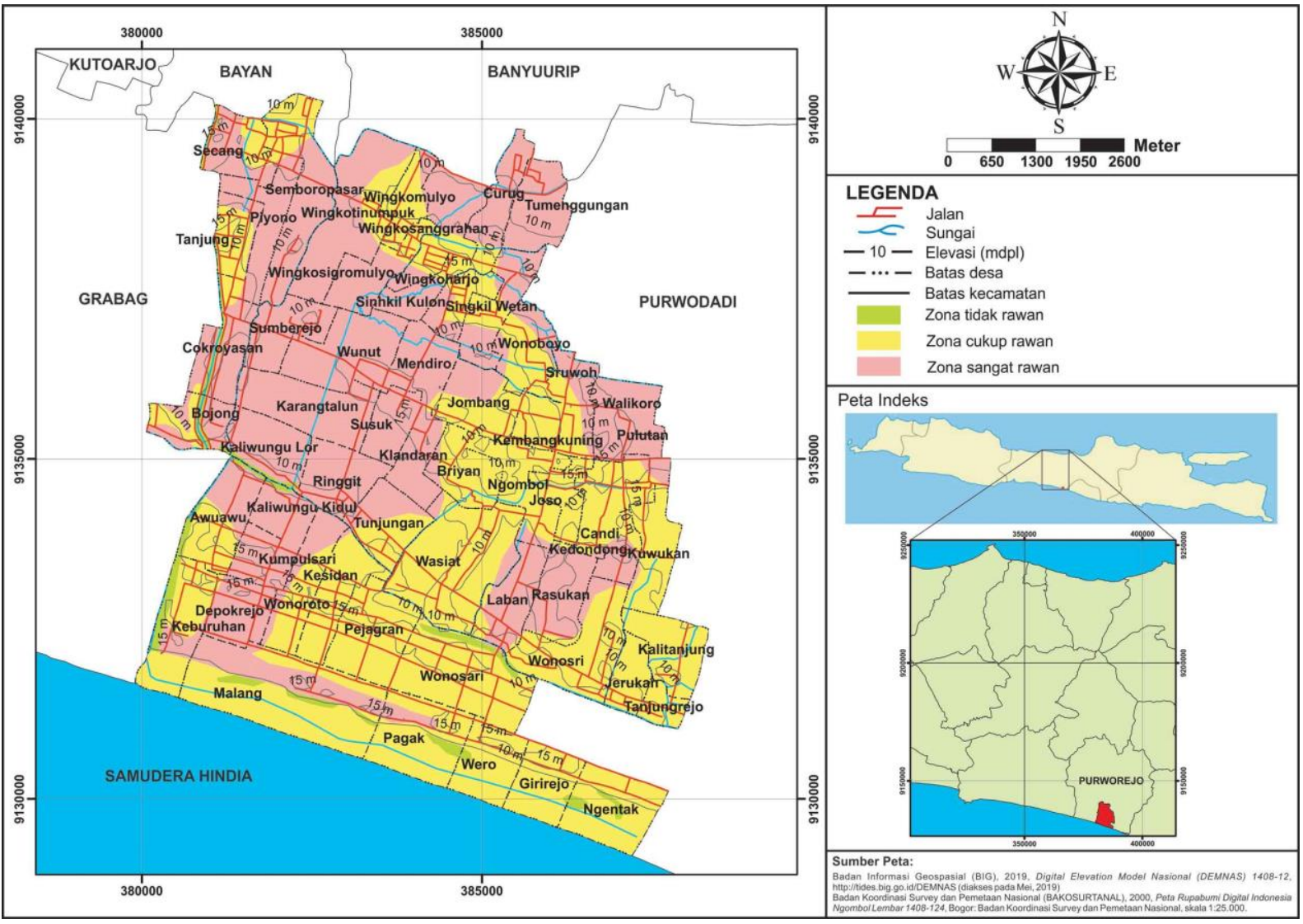

Gambar 10. Peta zona rawan bencana banjir Kecamatan Ngombol.

\section{KESIMPULAN}

Faktor dominan yang mempengaruhi persebaran tipologi kawasan rawan bencana gempabumi pada lokasi penelitian adalah faktor struktur geologi berupa zona sesar aktif yang jauh dari Kecamatan Ngombol serta faktor kemiringan lereng. Faktor dominan yang mempengaruhi potensi rawan bencana banjir pada daerah penelitian adalah faktor kemiringan lereng Kecamatan Ngombol yang relatif datar hingga landai serta kondisi tanah berupa aluvial yang sulit menyerap air.

Diperlukan adanya sosialisasi kepada masyarakat Kecamatan Ngombol dikarekanakan wilayah tersebut tergolong cukup rawan terhadap banjir sebagai tindakan preventif.

\section{UCAPAN TERIMA KASIH}

Penulis ucapkan terima kasih kepada Ajrun Ghairu Mamnun atas bantuan dalam melakukan pemetaan geologi dan Departemen Teknik Geologi UNDIP yang telah memberikan akses untuk penggunaan data.

\section{DAFTAR PUSTAKA}

Asikin, S., Handoyo, A., Busono, H., dan Gafoer, S., 1992. Peta Geologi Lembar Kebumen, Jawa, Bandung: Pusat Penelitian dan Pengembangan Geologi, skala 1:100.000.

ASTM Standard D2487, 2000. Standard Practice for Classification of Soils for Engineering Purposes (Unified Soil Classification System), West Conshohocken: ASTM International

Badan Informasi Geospasial (BIG), 2019. Digital Elevation Model Nasional (DEMNAS) 140802, http://tides.big.go.id/DEMNAS/ (diakses pada Mei, 2019)

Badan Meteorologi, Klimatologi, dan Geofisika, 2019. Gempabumi Tektonik M 5,1 Mengguncang Kabupaten Kulon Progo, Tidak Berpotensi Tsunami, http://www.bmkg.go.id/berita/?p=gempabum i-tektonik-m-51-mengguncang-kabupatenkulon-progo-tidak-berpotensitsunami\&lang=ID\&s=detil (diakses pada Mei, 2019)

Badan Nasional Penanggulangan Bencana, 2016. Resiko Bencana Indonesia, Jakarta: BNPB. 
Badan Nasional Penanggulangan Bencana, 2019. BENCANA ALAM KAB/KOTA (PURWOREJO) TAHUN 2008 S/D 2018, http://bnpb.cloud/dibi/tabel1a (diakses pada Mei, 2019)

Badan Pusat Statistik Kabupaten Purworejo, 2009. Kabupaten Purworejo dalam Angka, Purworejo: Badan Pusat Statistik Kabupaten Purworejo.

Badan Pusat Statistik Kabupaten Purworejo, 2010. Kabupaten Purworejo dalam Angka, Purworejo: Badan Pusat Statistik Kabupaten Purworejo.

Badan Pusat Statistik Kabupaten Purworejo, 2011. Kabupaten Purworejo dalam Angka, Purworejo: Badan Pusat Statistik Kabupaten Purworejo.

Badan Pusat Statistik Kabupaten Purworejo, 2013. Kabupaten Purworejo dalam Angka, Purworejo: Badan Pusat Statistik Kabupaten Purworejo.

Badan Pusat Statistik Kabupaten Purworejo, 2014. Kabupaten Purworejo dalam Angka, Purworejo: Badan Pusat Statistik Kabupaten Purworejo.

Badan Pusat Statistik Kabupaten Purworejo, 2015. Kabupaten Purworejo dalam Angka, Purworejo: Badan Pusat Statistik Kabupaten Purworejo.

Badan Pusat Statistik Kabupaten Purworejo, 2016. Kabupaten Purworejo dalam Angka, Purworejo: Badan Pusat Statistik Kabupaten Purworejo.

Badan Pusat Statistik Kabupaten Purworejo, 2017. Kabupaten Purworejo dalam Angka, Purworejo: Badan Pusat Statistik Kabupaten Purworejo.

Badan Pusat Statistik Kabupaten Purworejo, 2018. Kabupaten Purworejo dalam Angka, Purworejo: Badan Pusat Statistik Kabupaten Purworejo

Bronto, S., 2007. Genesis Endapan Aluvium Dataran Purworejo Jawa Tengah; Implikasinya Terhadap Sumber Daya
Geologi, Jurnal Geologi Indonesia, 2(4), 207 $-215$.

Dudal, R. dan M. Soepraptohardjo, M., 1957. Soil Classification in Indonesia, Contr. Gen. Agric. Res. Stat. Bogor, 148, 3-16.

Foth, H.D., 1990. Fundamentals of Soil Science Eight Edition, United States of America: John Wiley \& Sons.

Kementerian Pekerjaan Umum Republik Indonesia, 2007. Pedoman Penataan Ruang Kawasan Rawan Letusan Gunung Berapi dan Kawasan Rawan Gempa Bumi. Jakarta: Departemen Pekerjaan Umum Direktorat Jenderal Penataan Ruang.

Munsell Color, 1994. Munsell Color Chart Revised Edition, New York: Kollmorgen Instrument Corporation.

Nugroho, M.D.A., 2013. Identifikasi Zona Rawan Banjir Dengan Sistem Informasi Geografis (Studi Kasus: Sub DAS Dengkeng), Skripsi, Tidak Diterbitkan, Fakultas Teknik. Semarang: Universitas Diponegoro.

Robiana, R., Cipta, A., dan Omang, A., 2010. Peta Kawasan Rawan Bencana Gempabumi Provinsi Jawa Tengah, Bandung: Pusat Vulkanologi dan Mtigasi Bencana Geologi, skala 1:500,000.

United States Department of Agriculture, 1975. Soil Taxonomy: A Basic System of Soil Classification for Making and Interpreting Soil Surveys, Washington: United States Department of Agriculture.

van Zuidam, R.A., 1983. Guide to Geomorphology Aerial Photographic Interpretation and Mapping, ITC Enschede The Nederland.

Wibowo, N.B. dan Nurhaci, D.S., 2017. Analisa Shakemap dan Jenis Sesar Studi Kasus: Gempabumi Terasa Di Purworejo - Jawa Tengah, Indonesian Journal of Applied Physics, 7(1), $10-19$. 